\title{
THIS IS NOT A SCANDAL IN LUXEMBOURG
}

\section{Benoît Majerus}

ESKA | «Entreprises et histoire »

$2020 / 4 \mathrm{n}^{\circ} 101 \mid$ pages 75 à 87

ISSN 1161-2770

ISBN 9782747231220

Article disponible en ligne à l'adresse :

https://www.cairn.info/revue-entreprises-et-histoire-2020-4-page-75.htm

Distribution électronique Cairn.info pour ESKA.

(C) ESKA. Tous droits réservés pour tous pays.

La reproduction ou représentation de cet article, notamment par photocopie, n'est autorisée que dans les limites des conditions générales d'utilisation du site ou, le cas échéant, des conditions générales de la licence souscrite par votre établissement. Toute autre reproduction ou représentation, en tout ou partie, sous quelque forme et de quelque manière que ce soit, est interdite sauf accord préalable et écrit de l'éditeur, en dehors des cas prévus par la législation en vigueur en France. Il est précisé que son stockage dans une base de données est également interdit. 


\title{
THIS IS NOT A SCANDAL IN LUXEMBOURG
}

\author{
by Benoît MAJERUS
}

Centre for Contemporary and Digital History $\left(\mathrm{C}^{2} \mathrm{DH}\right)$

Professor of European History

University of Luxembourg

\begin{abstract}
L'effondrement, au début des années 1970, de l'Investors Overseas Services (IOS) a été désigné, par la plupart des médias européens, comme un scandale luxembourgeois, mais ce scandale n'a pas été caractérisé de la même manière au Luxembourg, que ce soit par la presse ou par les élites politiques. Cette étude de cas analyse les manières dont le scandale (financier) peut survenir et s'estomper dans les pays de petite taille.
\end{abstract}

In February 1968, Investors Overseas Services (IOS), a Panamanian company selling investment funds, was featured on the cover of the German weekly news magazine Der Spiegel. Erich Mende had just been appointed to represent IOS in Germany - a publicity coup that seemed to be bearing fruit. The portrait of the former German Vice Chancellor from the Free Democratic Party was emblazoned on the cover of the magazine along with the title "People's shares from Panama"1. In a country where a leading car brand has the word "people" (Volk) in its name, the IOS communication strategy was a great success: IOS founder Bernie Cornfeld spoke of a "people's capitalism". Two years later, in May 1970, the same weekly publication led with the cover story "Sellout at IOS"2. The articles accompanying these two covers painted a picture of the geography of this international company: the United States, Germany, France, Italy, Brazil, Switzerland, Panama, Liechtenstein, the Netherlands Antilles and Luxembourg. The first countries were described as potential and real markets for IOS, and the latter four, in the narrative recounted by Der Spiegel, were presented as powerhouses of the transnational tax engineering that emerged in the $1960 \mathrm{~s}^{3}$. While the tone of the 1968 article remained relatively neutral - "tax-privileged Luxembourg" 4 -, the 1970 article was more accusatory - "The pure net value of its over 60 companies, most of which are based in the tax havens of Luxembourg, Panama, the Bahamas and the Netherlands Antilles, was over 366 million marks" 5 . It was not the first time that Der Spiegel had placed Luxembourg in the category of tax havens ${ }^{6}$, but during the

\footnotetext{
1 "Volks-Aktien aus Panama", Der Spiegel, 26 February 1968.

2 “Ausverkauf bei IOS”, Der Spiegel, 18 May 1970.

${ }^{3}$ V. Ogle, "Archipelago Capitalism: Tax Havens, Offshore Money, and the State, 1950s-1970s", American Historical Review, vol. 122, n 5, December 2017, p. 1431-1458.

${ }^{4}$ Originally "Steuerbegünstigten Luxemburg”. "Wertpapiere - IOS: Das Kornfeld”, Der Spiegel, 26 February 1968.

${ }^{5}$ Originally "Der reine Nettowert seiner über 60 Gesellschaften, die ihren Sitz überwiegend in den Steueroasen Luxemburg, Panama, den Bahamas und den Niederländischen Antillen haben, betrug über 366 Millionen Mark"; "Wertpapiere - IOS: Völlig unrealistisch", Der Spiegel, 18 May 1970.

${ }^{6}$ See for example: “Industrie - Müller-Wipperführt: Der Steuer-Schneider”, Der Spiegel, 11 January 1961.
} 
period from 1968 to 1971 , during which the magazine covered IOS in detail, Luxembourg attracted particular attention.

The collapse of IOS was the first event that put the Luxembourg financial industry, still very limited in the late $1960 \mathrm{~s}$, on the map for the international press. The subsequent scandals that shook up the Luxembourg financial centre revealed practices that would otherwise have remained largely invisible both for contemporaries and for today's historians: Herstatt in 1974, Banco Ambrosiano in 1982, Bank of Credit and Commerce International (BCCI) in $1991^{7}$, Clearstream in 2004, Luxleaks in $2014^{8}$, etc.

In all these "affairs", the events were turned into scandals by people considered by the Luxembourg political class and the elite of the country's financial centre as "foreigners" often suspected of wanting to harm the financial centre. At the same time, elevating the events to the status of scandals shone a spotlight on certain practices, thereby exerting pressure to change the system that had allowed the scandal to happen even as the scandalous nature of the incident continued to be investigated. This article will look at the international media coverage of the collapse of IOS before examining the role played by the press in Luxembourg and the way in which regulatory authorities and political elites attempted to "close down" the scandal. While the press is just one player among many with the ability to decide whether an incident merits the status of scandal, it appears to have been the main sounding board when it came to IOS. Literature in the humanities and social sciences has tended to focus on examples of the press helping turn events into scandals; but in this case the press in Luxembourg played a part in bringing the scandal to a close ${ }^{9}$.

Investors Overseas Services was a company founded by an American, Bernie Cornfeld, in 1955, with its registered office in Panama ${ }^{10}$. After the Second World War, Cornfeld worked for a few years for the American investment management company Dreyfus, before setting up his own investment funds. The first and largest of these, the International Investment Trust (IIT), set up in 1961, was domiciled in Luxembourg with the Banque Internationale à Luxembourg. In 1959, probably in response to a request from business lawyers in Luxembourg including Bernard Delvaux, Luxembourg Finance Minister Pierre Werner had decided to apply the beneficial tax regime that governed Luxembourg holding companies to investment funds ${ }^{11}$. The IIT was one of the first funds to choose Luxembourg. In 1963, IOS set up its first bank, Investors Bank, in Luxembourg. By 1969, the company was managing $\$ 2,5$ billion and was one of the largest investment fund companies in the world $^{12}$. Although it has been impossible to trace the precise sequence of events that brought Cornfeld to Luxembourg, he liaised

\footnotetext{
${ }^{7}$ J. R. Adams, F. Douglas, A Full Service Bank: How BCCI Stole Billions around the World, New York, Simon \& Schuster, 1992

${ }^{8}$ F. Chaouche, Legitimate Expectations in Luxembourg Tax Law. A Study of Administrative Circulars and Tax Rulings Issued by the Luxembourg Tax Authorities, PhD, Université du Luxembourg, 2018.

9 J. B. Thompson, Political Scandal. Power and Visibility in the Media Age, Cambridge, Polity, 2008.

${ }^{10}$ The history of IOS has not yet been written, apart from its Swiss aspects (M. Perrenoud, "Le scandale de l'Investors Overseas Services (IOS). Les épisodes suisses dans les années 1960-1970”, in M. Mazbouri and F. Vallotton (eds.), Scandale et histoire, Lausanne, Éditions Antipodes, 2016, p. 53-80), but several accounts were published when it collapsed, even including a cartoon: M. Birkholz, W. Saller, IOS, Senkrechtstart und Absturz einer Erfolgsidee: die Inside-Story einer Investmentgesellschaft, Düsseldorf-Vienna, Econ-Verlag, 1970; Ch. Raw, G. Hogson, B. Page, Do You Sincerely Want to Be Rich? Bernard Cornfeld and IOS: an International Swindle, London, Andre Deutsch, 1971; B. Cantor, The Bernie Cornfeld Story, New York, L. Stuart, 1970; G. Pellizzi, Bernie der Milliardenflipper: ein tragischer Comic aus der Hochfinanz, Berlin, Rotbuch Verlag, 1974.

${ }^{11}$ B. Delvaux, "Les Sociétés d'Investissement du type ouvert au Grand-Duché de Luxembourg", in Pasicrisie luxembourgeoise, Luxembourg, Pasicrisie luxembourgeoise, 1961, p. 37-85. Interview by Benjamin Zenner with Jacques Delvaux, 17 July 2019.

${ }^{12}$ Ch. Raw, G. Hogson, B. Page, Do You Sincerely Want to Be Rich?, op. cit., p. 13.
} 
with Luxembourg stakeholders with links to the political arena and the fledgling financial centre. The Dupong law firm - whose members included Jean Dupong, member of parliament for the Christian Social People's Party (1954-1958, 1959-1967, 1974-1979), and Lambert Dupong, son of Luxembourg Finance Minister and Prime Minister Pierre Dupong (1937-1952) - represented Cornfeld in Luxembourg. The accounts were handled by Fiduciaire Générale, founded among others by Jean Hamilius, son of a Democratic Party (DP) member of parliament and himself a DP member of parliament (1968-1974) and minister (1974-1979). Cornfeld not only enjoyed a beneficial tax regime for his investment funds; he was also subject to a less strict regulatory framework, as demonstrated by the fact that he moved some of his business to Luxembourg once authorities in the US, especially the Securities and Exchange Commission (SEC), and in Switzerland began restricting his room for manoeuvre in their respective countries in the late 1960s. At the same time, Cornfeld's decision to choose Luxembourg offered the country considerable benefits. IOS was one of Fiduciaire Générale's biggest clients; from that point onwards the firm really took off, later becoming the basis for Deloitte Luxembourg ${ }^{13}$. For the BIL, as transfer agent and registrar, the fund represented a constant source ${ }^{14}$ of income, and when the regulatory framework changed following a new law in $1965^{15}$, it immediately asked the Banking
Commissioner (Commissaire au contrôle des banques) to bring the IIT into line, prior to the five other funds it managed, demonstrating just how important the fund was for the bank ${ }^{16}$. By opening the Investors Bank Luxembourg (IBL) in $1965^{17}$ and a branch of the Swiss Overseas Development Bank in 1966, Cornfeld also conferred a degree of international prestige on a financial centre, which at that point was European for the most part, with 23 establishments including fifteen Belgian-Luxembourgish banks, three French banks, and three American banks ${ }^{18}$.

\section{A FOREIGN SCANDAL FOR FOREIGNERS?}

The collapse of IOS garnered considerable media attention; it was a "media event in a global age" 19 . The number of investors for IIT, estimated at 144000 in $1972^{20}$, and the exuberant personality of Bernie Cornfeld gave the story a particular resonance. The aim of this article is not to provide a detailed timeline of events but rather to identify the role assigned to Luxembourg by three major European media outlets ${ }^{21}$. A brief overview of articles published in two daily newspapers and a weekly news magazine whose archives are accessible online does allow us to sketch out an initial transnational chronology.

\footnotetext{
${ }^{13}$ Interview by the author with Jean Hamilius (19 December 2017). J. Hamilius, Luxemburg im Wandel der Zeiten: Erinnerungen (1927-2014), Luxembourg, Binsfeld, 2014, p. 123-124.

${ }^{14}$ BIL, Rapports et Bilan pour l'Exercice 1960, Luxembourg, BIL, 1961, p. 28.

${ }^{15}$ Arrêté-loi du 19 juin 1965 relatif aux émissions, offres et ventes publiques de valeurs mobilières.

16 Archives Nationales du Luxembourg (ANL), Commission de Surveillance du Secteur Financier (CSSF), investment fund, box 9816, letter from the Banque Internationale à Luxembourg to the Banking Commissioner (4 September 1969).

${ }^{17}$ In 1971, IBL changed its name to Overseas Development Bank Luxembourg.

18 Statistiques historiques : 1839-1989, Luxembourg, STATEC, 1990, p. 344. For a short chronology of the Luxembourg financial centre: B. Majerus, B. Zenner, "Too Small to Be of Interest, Too Large to Grasp? Histories of the Luxembourg Financial Centre", European Review of History: Revue européenne d'histoire, vol. 27, n 4, 2020 , p. $548-562$. ${ }^{19}$ C. Nick, A. Hepp, F. Krotz (eds.), Media events in a global age, London, Routledge, 2009.

${ }^{20}$ ANL, CSSF, box 16656, letter from Joseph Kauffman to Georges Baden (31 July 1981).

${ }^{21}$ The documentary basis for this section is a collection of press cuttings compiled by the Banking Supervisory Authority. ANL, CSSF, box 115, and a systematic exploration of French newspaper Le Monde, British newspaper The Guardian and German news magazine Der Spiegel. The press collection mainly includes articles from the German press.
} 
Table 1 - Numbers of articles on IOS in Der Spiegel (German weekly news magazine), Le Monde (French daily newspaper) and The Guardian (British daily newspaper)

\begin{tabular}{|l|c|c|c|c|c|c|c|c|c|c|c|c|c|c|c|}
\hline \multicolumn{1}{|c|}{ Year } & 1965 & 1966 & 1967 & 1968 & 1969 & 1970 & 1971 & 1972 & 1973 & 1974 & 1975 & 1976 & 1977 & 1978 & 1979 \\
\hline Der Spiegel & 1 & 0 & 2 & 10 & 6 & 26 & 6 & 12 & 9 & 9 & 5 & 3 & 4 & 5 & 1 \\
\hline Le Monde & 0 & 1 & 5 & 0 & 2 & 21 & 6 & 1 & 3 & 1 & 5 & 3 & 5 & 1 & 3 \\
\hline The Guardian & 1 & 0 & 2 & 0 & 1 & 42 & 15 & 3 & 15 & 6 & 4 & 2 & 6 & 8 & 12 \\
\hline
\end{tabular}

For Le Monde and The Guardian, Luxembourg was not a significant player. In the 58 articles published by Le Monde, Luxembourg receives only four mentions. A single article explicitly criticises Luxembourg's position: "From 1960 to 1969 IOS was a Panamanian company, and in June 1969 it became a Canadian holding company. It gradually acquired a banking sector and insurance operations through multiple companies based in all the tax havens, or at least everywhere where there were legislative loopholes: Switzerland, the Bahamas, Luxembourg, Canada" 22 . Moreover, Le Monde barely "scandalised" the collapse of IOS. The same was true of The Guardian: of the 117 articles on IOS, only two refer to Luxembourg, one of which presents Luxembourg as taking the necessary measures after the collapse of several investment funds: "The Grand Duchy of Luxembourg, home base for many funds, is issuing new instructions to managers, copied from the stiff West German law"23.

Der Spiegel, however, presented an entirely different version ${ }^{24}$. Of the 100 articles published by the German weekly news magazine, ten refer to Luxembourg and six assign Luxembourg a key role in the narrative. In mentioning Luxembourg, the journalists primarily intended to point the finger at the lack of transparency of IOS's international structure. In the first article where IOS and Luxembourg are mentioned together - an interview with Erich Mende -, the two authors emphasise that Luxembourg was chosen to elude the German tax authorities and that the Luxembourgish legislative framework provided barely any protection for investors ${ }^{25}$. Other German media also criticised Luxembourg in their reporting on IOS. Der Aktionär, a German weekly business and finance magazine, wrote in 1971 that "The Grand Duchy is rich in iron ore, game and especially wild boar, but poor in securities laws" and emphasised the role played by the Banque Internationale à Luxembourg in legitimising the IIT $^{26}$.

A second wave of media coverage hit Luxembourg once the liquidation process had begun. In 1973, the Luxembourg courts placed the IIT in liquidation, and two Luxembourg lawyers, Georges Baden and Jacques Delvaux, and one accountant, Ernest Lecuit, were appointed as liquidators. At the same time, the Banking Commissioner, in cooperation with the US Securities and Exchange Commission and two Canadian supervisory authorities,

\footnotetext{
${ }^{22}$ Originally: "IOS est de 1960 à 1969 une compagnie de droit panaméen, et, à partir de juin 1969, une société holding de droit canadien. Elle s'adjoint peu à peu un secteur bancaire et des activités d'assurance dans une multitude de sociétés implantées dans tous les paradis fiscaux, partout en tout cas où la législation comporte quelques lacunes : Suisse, Bahamas, Luxembourg, Canada". M. Kajman, "La chute de l'empire", Le Monde, 15 juin 1977.

${ }^{23}$ N. McInnes, "New Controls Proposed for Offshore Funds", The Guardian, 1 December 1971.

${ }^{24}$ Press coverage in Germany was generally more extensive than in other countries: at least half of the 140000 investors came from Germany.

${ }^{25}$ K. Blauhorn, R. Schneider, "Schon einige Millionen Dollar eingebracht”, Der Spiegel, 15 January 1968.

${ }^{26}$ Originally: "Das Grossherzogtum ist reich an Eisenerzen, Wild und vor allem Wildschweinen, aber arm an Wertpapiergesetzen”. "Neueste Enthüllungen über IOS. Teil 2: Die üblen Tricks mit dem IIT”, Der Aktionär, 5 July 1971, p. 17-18.
} 
embarked on a hunt for the assets belonging to the holding company for the vast IOS network. It was once again the German press that was most critical of Luxembourg's position, but there were also disparaging articles in Belgian and US newspapers ${ }^{27}$. The creation of the International Association of Shareholders of IOS Funds (IASIF) brought a new player into the arena. Composed mainly of German investors and led by Berlin-based lawyer Gerold Bezzenberger, this group helped publicise the case with articles in the press ${ }^{28}$. An article published by the IASIF lawyer in 1973 in a magazine aimed at investors criticised Luxembourg's position in the liquidation ${ }^{29}$.

There was significant media coverage of IOS in Germany, but the issue did not reach the parliamentary arena, although in 1968 the German government did introduce legislation to step up controls on investment funds. At that point, Luxembourg was openly referred to as a place that, although lacking in specific controls, had "well-known investment companies that have worked perfectly so far" ${ }^{30}$.

\section{MEDIA COVERAGE IN LUXEMBOURG}

In Luxembourg, it was also the press that brought the events surrounding IOS to the public eye. In the late 1960s, the Luxembourg press was characterised by its diversity. For a population of 340000 , there were five daily newspapers, all but one of which were more or less directly linked to political groups. The Luxemburger Wort, owned by the diocese, had the largest circulation, the Tageblatt belonged to the socialist trade union, the Journal was close to the Democratic Party and the Zeitung vum Lëtzebuerger Vollek close to the Communist Party. There was also the Républicain Lorrain, an independent French newspaper published in Metz which had a regional edition for Luxembourg since 1961. Two weekly publications, the mainstream magazine Revue and d'Lëtzebuerger Land, aimed at the business community, completed this press line-up ${ }^{31}$.

When IOS came to Luxembourg in the early 1960s, it became a regular advertiser in the daily press $^{32}$. Approximately 4000 to 4500 Luxembourgers invested in the funds proposed by IOS $^{33}$. In 1970s, the Investors Bank Luxembourg, which managed customer service for the investment funds, moved into a new building in one of the most prestigious streets in Luxembourg City, avenue de la Liberté, opposite the headquarters of ARBED, the steel company that had been a highly influential presence in Luxembourg for several decades. The move generated considerable media interest: the Républicain Lorrain described the bank as "a very strong banking and financial institution with an

\footnotetext{
${ }^{27}$ See for example: "L'affaire IOS - Un épilogue au Grand-Duché", Écho de la Bourse, 5 February 1975 and "Agreement Reached to Free I.O.S. Funds", The New York Times, 29 June 1973, p. 57.

${ }^{28}$ Der Spiegel, Die Bunte, Wertpapier.

${ }^{29}$ G. Bezzenberger, "IOS-Liquidation: Wurden Chancen verpasst. Ein Bericht der IASIF", Das Wertpapier, July 1974 , p. 467-471.

${ }^{30}$ Originally "Bekannten und bisher einwandfrei arbeitenden Investmentgesellschaften”. Entwurf eines Gesetzes über den Vertrieb ausländischer Investmentanteile, über die Besteuerung ihrer Erträge sowie zur Änderung und Ergänzung des Gesetzes über Kapitalanlagesellschaften, 13 November 1968, Drucksache V/3494, p. 15.

${ }^{31}$ The documentary basis for this chapter is a collection of press cuttings compiled by the Banking Commissioner (ANL, CSSF, boxes 114 and 115) and a systematic exploration of the weekly newspaper d'Lëtzebuerger Land. A request to the Centre National de l'Audiovisuel (CNA), which manages radio archives, did not yield any results, but the referencing of these archives is limited.

${ }^{32}$ For example Luxemburger Wort on 12 July 1969 with a one-page advertisement promoting the yields of the International Investment Trust.

${ }^{33}$ R. Reuter, "I.O.S. Tales of Woe and Crafty Salesmen”, Luxembourg Weekly Review, 26 July 1974, p. 8-13.
} 
Table 2 -Timeline of articles in the Luxembourg press

\begin{tabular}{|c|c|c|c|c|c|c|c|c|c|}
\hline Year & 1970 & 1971 & 1972 & 1973 & 1974 & 1975 & 1976 & 1977 & $1978-1982$ \\
\hline Number of articles & 18 & 7 & 3 & 5 & 9 & 7 & 0 & 6 & 2 \\
\hline
\end{tabular}

excellent reputation" ${ }^{34}$. The article was published in December 1970 at a time when the Luxembourg and foreign press were already widely reporting on the problems of IOS.

The first article in the Luxembourg press to mention problems with IOS was published in the Tageblatt in the "Domestic policy" section in May 1970, the same month that Der Spiegel published its critical cover following a two-thirds drop in the value of IOS shares in a matter of weeks. The article, a reproduction of a contribution published in the German Süddeutsche Zeitung, was accompanied by two specific additions for its publication in Luxembourg. In an introductory paragraph, the journalist emphasised that there had been compliance with Luxembourg law in terms of the products offered by IOS and that all stock market activity is risky - a narrative that would be repeated several times in Luxembourg's media coverage. In conclusion, the journalist expressed hopes that "the state banking supervisory authority will monitor the current IOS situation with the utmost attention, since Luxembourg interests are involved" ${ }^{35}$. An inset with highly ironic overtones, entitled "And what do the IOS colonels say?" ${ }^{36}$, also described a situation that had helped build the scandal abroad. As it had done in other countries - for example with James Roosevelt, elder son of US President Franklin D. Roosevelt in the United States, and the aforementioned Erich Mende in Germany -, IOS also involved public figures in Luxembourg to boost the company's legitimacy. The system for the sale of investment funds was supported in Luxembourg by Robert Winter, former Chief of Staff of the Luxembourg Army, and Émile Krieps, a former colonel in the Luxembourg Army and Democratic Party MP in the early $1970 \mathrm{~s}^{37}$. Without naming them specifically, the paragraph concluded cynically that "IOS savers can rest assured. The retired Luxembourg colonels have guards outside the IOS vaults" 38 .

A few days later, Ernest Mühlen reported on IOS in the Lëtzebuerger Land. The article followed a press conference held in Luxembourg on 15 May by James Roosevelt, Vice-Chairman of IOS Limited ${ }^{39}$. A trained economist, Mühlen was working at that time for the European Coal and Steel Community. In the 1960s, he wrote several books on the Luxembourg financial centre and explored the

\footnotetext{
${ }^{34}$ Originally: "Une institution bancaire-financière éminemment solide à réputation excellente”. "Investors Bank Luxembourg S.A. a ouvert dans un nouveau cadre", Le Républicain Lorrain, 22 December 1970.

${ }^{35}$ Originally: "Die staatliche Bankkontrolle die augenblickliche Lage der IOS, soweit Luxemburger Interessen vorhanden sind, mit grösster Aufmerksamkeit verfolgt".

${ }^{36}$ Originally: "Und was sagen die IOS-Colonels?".

${ }^{37}$ ANL, CSSF, box 116, list of IOS delegates in Luxembourg, 4 December 1969.

${ }^{38}$ Originally: "Die IOS-Sparer können beruhigt sein. Die Luxemburger Colonels a.D. stehen Wachen vor den IOS-Tresors". "IOS-Finanztrust im Rampenlicht", Tageblatt, 5 May 1970.

${ }^{39}$ The Roosevelt family had a particular resonance in Luxembourg, especially because of the links between Franklin Roosevelt and Grand Duchess Charlotte. Cf. Th. Grosbois, "L'attitude de Roosevelt à l'égard du devenir du Luxembourg", in Ët wor alles net esou einfach. Questions sur le Luxembourg et la Deuxième Guerre mondiale, Luxembourg, Musée d'histoire de la ville de Luxembourg, 2002, p. 198-223.
} 
development of investment funds in articles for the Land" ${ }^{40}$. With the headline "IOS at the crossroads" ${ }^{41}$, the article referred to the departure of IOS founder Bernie Cornfeld. It qualified events by referring to an "IOS Krise" but one that was on its way to being resolved. In Mühlen's view, the causes of the "crisis" were structural: "It would be wrong to look for the source of all the difficulties facing IOS exclusively within the investment company itself. The reasons are much more general. A first observation is obvious in this context. The fall in Wall Street prices in 1969 - and to a greater extent in 1970 - was extremely unfavourable to mutual funds that invested their assets in American securities" ${ }^{22}$.

In early articles in summer 1970 , the Luxembourgish press spoke of the "crisis". But very soon after that, the Tageblatt used the word "affair" in a context in which the behaviour of the Luxembourg authorities was being called into question over the decision to continue allowing IOS Ltd and IOS Management shares to be traded on the Luxembourg Stock Exchange once Toronto and London had withdrawn them from their respective stock exchange ${ }^{43}$. The Luxemburger Wort also raised questions with regard to the Luxembourg authorities, especially the legislative capability of the country's banking supervisory system to prevent such crises. The word "scandal" only appeared in the Républicain Lorrain at the point at which the funds were being liquidated, in the mid-1970s.
But the reasons for using the term were not clarified and it was not linked to an institution, a person or a country in particular ${ }^{44}$. In a long article, L'employé, the monthly publication of the Fédération des employés privés du GrandDuché de Luxembourg, raised the question of the need for new regulations, but its main point was the theory that an overly high tax rate was encouraging people to invest in such risky products ${ }^{45}$.

After the first year of reporting, in which Luxembourg media coverage contained details that could have been characterised as "scandalous" - weak Luxembourg regulations, support for the IOS from some eminent members of Luxembourg society, etc. -, such articles became few and far between. The Luxemburger Wort overtly began presenting a contrasting narrative. The paper - traditionally close to the governing Christian Social People's Party, the party of Finance Minister Pierre Werner - painted a very positive picture of the Banking Commissioner, Albert Dondelinger. An article published in July 1974 was a clear example of this "de-scandalisation" approach. With the headline "Speedy processing of IOS liquidation continues", the journalist paraphrased statements by Dondelinger - "New successes to report" - which were not challenged ${ }^{46}$. This narrative was in contradiction with some foreign press, which saw the slow pace of the liquidation process as part of the scandal. Even the Républicain Lorrain, highly critical at the outset, now maintained

\footnotetext{
${ }^{40}$ E. Mühlen, Le marché financier luxembourgeois face à la conversion industrielle, Luxembourg, Buck, 1963; E. Mühlen, "Les fonds de placement au Luxembourg", d'Letzeburger Land (article in three parts: I, n 3, 17 January 1964, p. 3. II, 24 January 1964, n 4, p. 7 ; III, 31 January 1964, n 5, p. 7.

${ }^{41}$ Originally: "IOS am Scheideweg".

42 Originally: "Es wäre falsch, die ganzen Schwierigkeiten, denen sich die IOS im Augenblick gegenübersieht, ausschliesslich im Rahmen dieses Investmentunternehmens zu suchen. Die Gründe sind viel allgemeiner. Eine erste Feststellung drängt sich in diesem Zusammenhang auf. Der Kursrückgang von Wall Street im Jahre 1969 - und in einem verstärkteren Masse noch im Jahre 1970 - war den Mutual Funds, sofern sie ihre Einlagen in amerikanischen Wertschriften anlegen, äusserst ungünstig." E. Mühlen, "IOS am Scheideweg”, d'Lëtzebuerger Land, 22 May 1970. 43 “Die IOS-Affäre: Notiz an der Luxemburger Börse nicht unterbrochen”, Tageblatt, 24 June 1970.

44 “Affaire IOS - À la recherche de fonds... et d'investisseurs !”, Républicain Lorrain, 22 May 1977.

45 "IOS und kein Ende", L'employé, n 10, October 1970, p. 4.

${ }^{46}$ Originally "Neue Erfolge zu verzeichnen”. "Weiterhin zügige Abwicklung der IOS-Liquidation”, Luxemburger Wort, 7 December 1974.
} 
that "it is in Luxembourg, however, that the quickest work has been done" 47 . It is worth noting that the liberal press outlet, Journal, remained generally silent on IOS, a fact that can probably be explained by the involvement of at least one member of the Democratic Party in the IOS affair.

The Luxembourg press was not of the view that there was any scandal at international level either. Aspects such as Cornfeld's sexual lifestyle or his ostentatious shows of wealth highlighted by magazines like Der Spiegel and Der Stern and also by daily newspapers like the Handelsblatt - barely received a mention in Luxembourg ${ }^{48}$. Bernie Cornfeld did appear in some articles but with no real critique; he was simply referred to as the "investment genius" (Investmentgenie) in quotation marks. The result was that the scandal was not personalised to any particular extent. While the international press provided extensive coverage of Bernie Cornfeld's trial in Geneva in the late 1970s, the Luxembourg press seemed largely indifferent to the proceedings.

\section{"VICTIMS" REMAINING SILENT}

In events labelled as scandals, those who claim to be victims often play an important role. But their involvement is sometimes hindered by the potential for "collateral damage".
In the contaminated blood scandal, the stigmatisation of patients who had been infected with a sexually transmitted disease considered by some as shameful explains why it was hard to organise the "victims" - as some haemophiliacs did not want to be grouped together with homosexuals ${ }^{49}$. In the case of IOS, it was also hard to mobilise fund holders since to a certain extent the behaviour of investors was also seen as problematic. In an article published in August 1970 in the socialist daily newspaper Tageblatt, economic journalist Joseph Hanck openly criticised Luxembourg fund holders: "Many Luxembourg purchasers of IOS investment certificates had in mind that they were cheating the tax authorities, which they often succeeded in doing" ${ }^{50}$. This article elicited a reaction from a holder of shares in an investment fund. The individual, who had invested in the "Fund of Funds" investment fund, the only product offered by IOS to Luxembourgers that enabled them to evade the Luxembourg tax authorities, gave a stinging attack of the Banking Commissioner: "The state authorities in Belgium, Germany and Switzerland protect their unsuspecting citizens [...]. But this is not the case in Luxembourg [:] in this case the Banking Commissioner failed miserably and only prohibited the sale of FOF shares when they were worth nothing" 51 . The author of the letter was immediately taken to task by a journalist for the Tageblatt, who defended the Banking Commissioner and called on future investors to be less naive,

\footnotetext{
${ }^{47}$ Originally: “C'est au Grand-Duché cependant que l'on a travaillé le plus rapidement”. "M. Albert Dondelinger à propos de la Overseas Development Bank: tous les déposants devraient être remboursés", Le Républicain Lorrain, May 1975. The Overseas Development Bank belonged to the IOS empire.

${ }^{48}$ Many authors who have researched scandals emphasise these two aspects - sex and wealth - as being particularly conducive to scandal: J. B. Thompson, Political Scandal. Power and Visibility in the Media Age, Cambridge, Polity, 2008, p. 15.

${ }^{49}$ M. Pollak, "Constitution, diversification et échec de la généralisation d'une grande cause. La lutte contre le Sida", Politix. Revue des sciences sociales du politique, vol. 4, n 16, 1991, p. 80-90.

${ }^{50}$ Originally: "Bei vielen luxemburgischen Erwerbern von IOS-Investmentzertifikaten spielte der Gedanke mit, dem Fiskus ein Schnippchen zu schlagen, was ihnen oftmals gelang". J. Hanck, "Luxemburger IOS-Aktionäre und IOS-Investmentkunden", Tageblatt, 17 August 1970.

${ }^{51}$ Originally: "Die staatlichen Autoritäten in Belgien, Deutschland und in der Schweiz beschützen ihre ahnungslosen Bürger [...]. Das ist aber nicht der Fall in Luxemburg [:] in diesem Falle hat der Kommissar kläglich versagt und den Verkauf von FOF-Anteilen erst untersagt, als diese nichts mehr wert waren." "Briefe an das Tageblatt - IOS-geschädigter Investmentkunde", Tageblatt, 22 August 1970.
} 
and by another reader of the newspaper, who criticised the investor's carelessness.

The potential to "name and shame" for negligence or tax evasion probably also explains why investors never initiated court proceedings; had they done so, it may have added fuel to the scandal. Some journalists emphasised this back in 1973: "No one ever made a complaint against IOS. This is a remarkable finding in two respects. First, it is very likely that some of the investors did not want to disclose their losses voluntarily perhaps to spare themselves from the gloating of others, but perhaps also because they knew that the tax authorities were curious and they feared having to explain where the money they had lost came from" 52. And this "reluctance" did not only apply to Luxembourg. Even the aforementioned International Association of Shareholders of IOS Funds (IASIF) mainly communicated through its lawyer and did not publicise individual cases.

The Union Luxembourgeoise des Consommateurs (Luxembourg consumer protection association - ULC), set up in 1961 by Luxembourg trade unions, did set out to help defend Luxembourg investors, but it avoided creating a scandal in Luxembourg. Although its magazine De Konsument referred to the "Financial scandal of the $20^{\text {th }}$ century", the article itself does not actually explain the nature of the scandal. Luxembourg is presented as a simple victim: the ULC emphasises the severity of controls in the United States and Germany, without mentioning the absence of similar controls in Luxembourg ${ }^{53}$. Rather than investigating the action of the Banking Commissioner, it preferred to work in cooperation with him by collecting documents from Luxembourgish and non-Luxembourgish asset holders. For the young organisation, the IOS collapse significantly boosted its membership ${ }^{54}$.

\section{REGULATING TO CHANGE NOTHING}

Luxembourg's resolution of the crisis involved implementing new regulations. Several countries had regulated sales of investment funds in the 1950s. The US Securities and Exchange Commission had been applying particularly strict rules since 1940 . In 1957, it banned IOS from continuing to sell funds to US citizens ${ }^{55}$. The Belgian Banking Commission banned the distribution of IOS investment funds because it contravened the regulations governing Belgian mutual funds ${ }^{56}$. Germany introduced legislation in the field for the first time in 1957 and then in 1969, the latter law forcing IOS to stop distributing some funds in Germany. In Luxembourg, the Grand-Ducal decree of 19 June 1965 on public offerings and sales of securities was published but it did not include specific rules for investment funds.

The collapse of IOS compelled the Luxembourg authorities to react. The GrandDucal decree for the control of investment funds of 22 December 1972, proposed by Finance Minister Pierre Werner and probably drafted by the Banking Commissioner Albert Dondelinger, did not explicitly mention IOS in its preamble. It said that the investment fund industry had experienced "a serious crisis

\footnotetext{
${ }^{52}$ Originally: "Dass bisher niemand gegen die IOS klagte. Das ist eine in doppelter Hinsicht bemerkenswerte Feststellung. Zum einen liegt die Vermutung sehr nahe, dass ein Teil der Anleger ihre Verluste nicht freiwillig offenbaren wollten - vielleicht, um sich die Schadenfreude ihrer Mitmenschen zu ersparen, vielleicht aber auch, weil sie die neugierige Steuerverwaltung im Blick hatten und befürchteten, über die Herkunft des verlorenen Geldes Rechenschaft ablegen zu müssen.” J.-M. Meyer, “Randbemerkungen”, d'Lëtzebuerger Land, 6 July 1973.

53 “IOS - Der Finanzskandal des 20. Jahrhunderts", De Konsument, n 7, 1973, p. 8-13.

${ }^{54}$ Interview with Roby Meis, 10 May 2017.

55 "IOS - Rettung nach der Pleite", Capital, n 6, 1970, p. 71-77.

56 “Un géant de la finance serait en difficulté", Le Soir, April 1970.
} 
triggered by the collapse of stock prices on Wall Street" and that some funds had sometimes used "means of publicity that clearly aimed to mislead the public" ${ }^{57}$. It emphasised that the strengthening of legislation was part of a broader movement, particularly citing the United States, Switzerland, Germany and Italy. But the proposed solution remained highly flexible, giving the Banking Commissioner considerable discretionary power: "It seems preferable to address the subject in the same way as for banking supervision, by organising supervision and giving the body in charge of implementing it the power to recommend flexible but precise guidelines to the profession, which will allow development but will not stifle the most valuable initiatives" ${ }^{58}$. The compulsory opinion of the Chamber of Commerce, a corporate chamber for employers (trade, industry and banks), also pointed out that the Grand-Ducal decree would not slow down the activities of the financial centre. The Chamber of Commerce supported the decree "primarily because these provisions represent a vital instrument for maintaining and strengthening the credibility of the financial centre", and concluded that the "Chamber of Commerce is all the more comfortable in approving the text knowing that it has been drawn up in close collaboration with representatives from local banks, who belong to our Chamber" 59 .

For the Council of State, a consultative assembly to which all bills in Luxembourg must be submitted for an opinion, the reputation of the financial centre was also crucial, more so than protecting (Luxembourgish) savers, for example: "The protection of international savings is clearly a sufficiently important aim to justify extending the aforementioned control measures in these areas. But the decisive reason seems to be the protection of the good reputation of the Luxembourg financial centre". The Council of State even emphasised the urgency of the situation given "the imminent accession of the United Kingdom to the Community of Nine, where the power of the City may jeopardize the position acquired by Luxembourg on the market of Euro-dollar issues" ${ }^{60}$. The new decree was innovative on three levels: investment funds had to inform the Banking Commissioner of their financial situation on a monthly basis, this situation had to be verified by an independent expert and a list of investment funds drawn up by the Banking Commissioner had to be published at regular intervals ${ }^{61}$.

\footnotetext{
${ }^{57}$ Originally: "Une profonde crise déclenchée par l'effondrement des cours à Wall Street" [...] avec "parfois des moyens de publicité ayant pour but d'induire manifestement le public en erreur". Chambre des Députés - Luxembourg, 1972-1973, vol. 2, p. 1344. It is however clear that the decree was written to handle the IOS crisis: Interview by B. Zenner with H. Noel and C. Stuck, members of the Banking Commissioner in the 1970s (15 July 2019) and J. Delvaux (17 July 2019), one of the three liquidators of the IIT fund.

${ }^{58}$ Originally: "Il semble préférable d'aborder le sujet de la même manière que cela se fait en matière de surveillance de l'activité bancaire : en organisant la surveillance et en laissant à l'organe chargé de celle-ci d'user de son pouvoir de recommandation pour donner à la profession des lignes de conduite souples mais précises, qui permettent une évolution sans stériliser les initiatives les plus valables". Chambre des Députés - Luxembourg, 1972-1973, vol. 2, p. 1346. My emphasis.

${ }^{59}$ Originally: "Pour la raison majeure que ces dispositions constituent un instrument indispensable en vue de maintenir et de renforcer le caractère sérieux de la place financière" [...] "[La] Chambre de Commerce est d'autant plus à l'aise à approuver ce texte qu'il a été élaboré en étroite collaboration avec les représentants des banques locales qui sont des ressortissants à notre Chambre.” Chambre des Députés - Luxembourg, 1972-1973, vol. 2, p. 1349.

${ }^{60}$ Originally: "La protection de l'épargne internationale est certainement un objectif suffisamment important pour justifier l'extension des mesures de contrôle prémentionnées à ces titres. Mais la raison décisive semble bien résider dans la protection du bon renom des place financière de Luxembourg" [...] [and] "L'entrée imminente du RoyaumeUni dans la Communauté des neuf, où la puissance de la City risque de menacer les positions acquises par la place de Luxembourg sur le marché des émissions en euro-dollars". Chambre des Députés - Luxembourg, 1972-1973, vol. 2, p. 1352 .

${ }^{61}$ A. Biel, Ch. Stuyck, Les fonds d'investissement en droit luxembourgeois, Luxembourg, Institut universitaire international, 1978.
} 
Table 3 - Sales of investment fund securities in Luxembourg (in millions of Luxembourg francs) ${ }^{62}$

\begin{tabular}{|c|c|c|c|c|c|c|c|c|}
\cline { 2 - 10 } & 1968 & 1969 & 1970 & 1971 & 1972 & 1973 & 1974 & 1975 \\
\cline { 2 - 9 } & 1305 & 1912,7 & 1025,3 & 2504,6 & 1357,7 & 1078,3 & 396,1 & 963.1 \\
\hline Adjusted for inflation & 1305 & 1845,3 & 951,2 & 2205,4 & 1131,1 & 841,2 & 278,5 & 605.5 \\
\hline
\end{tabular}

For Luxembourg's fledgling financial industry, reputation was vital. The investment fund industry had experienced considerable growth in the late 1960 s, with several foreign players showing an interest in setting up in Luxembourg. In March 1970, a few weeks before the IOS collapse was reported in the press, one of the most influential law firms in the Luxembourg financial centre, after discussing the issue verbally with several representatives of the major banks, asked the Banking Commissioner to ease supervisory controls so that investment funds could be launched on the market more easily ${ }^{63}$. But this fledgling industry was hit hard by the collapse of IOS.

The Grand-Ducal decree was implemented over a period of several years. It was discussed by a committee set up by the Banking Commissioner and composed of financial stakeholders ${ }^{64}$. In mid-1974, the chairman of the "Securities" committee, Jean Nicolas Schaus, seemingly rather exasperated, complained that "supervision of investment funds was provided in the Grand-Ducal decree of 22 December 1972, and so it is high time to organise such supervision" so as to "maintain the good reputation of the financial centre" 65 . It was not until November 1974 and January 1976 that the first ministerial decrees setting out detailed obligations under the 1972 decree were issued. But Switzerland refused to recognise any equivalence between the supervision applied in Luxembourg and that applied in Switzerland in the area of investment funds, since "supervision in Luxembourg is based on information and not on management" 66 . Throughout the discussions, the committee sought to guarantee the "flexibility [...] that has always inspired the supervision of financial institutions" ${ }^{67}$. A bill proposed by Justice Minister Eugène Schaus that would impose stricter controls over mutual funds did not survive the committee's criticism.

These new regulations put an end to the (low-level) public debate in Luxembourg. Cornfeld's trial in Geneva in the late 1970s did not revive the debate, and the liquidation

\footnotetext{
62 ANL, CSSF, investment funds, box 9813, VM/VRFI/9+10 (probably from 1978). Many thanks to Matteo Calabrese and Paul Zahlen for the inflation adjustment.

${ }^{63}$ ANL, CSSF, investment funds, box 9816; letter from André Elvinger to Albert Dondelinger (5 March 1970).

${ }^{64}$ As well as three representatives of the Banking Commissioner (Albert Dondelinger, Jean-Nicolas Schaus and Charles Stuyck), it was composed of André Coussement, a representative of Kredietbank Luxembourg who was very active in investment funds; Jacques Delvaux, a business lawyer who in the early 1970s helped several foreign banks set up in Luxembourg - he was also one of the liquidators of the IOS investment funds; André Elvinger, a business lawyer; Edmond Israël, representative of the BIL which had been the depositary bank for IOS funds; Remy Kremer, representative of the Banque Générale du Luxembourg; and Ernest Lecuit, an accountant and one of the liquidators of the IOS investment funds.

${ }^{65}$ Originally: "La surveillance des fonds d'investissement a été prévue par l'arrêté grand-ducal du 22 décembre 1972 et que dès lors il est temps d'organiser cette surveillance" [...] [et de] "maintenir la bonne réputation de la place financière". ANL, CSSF, box 16663, report of the "Securities" meeting held on 31 May 1974.

${ }^{66}$ Originally: "Le contrôle luxembourgeois porte sur l'information et non sur la gestion”. ANL, CSSF, box 16663, report of the "Securities" meeting held on 24 May 1972.

${ }^{67}$ Originally: “ $[\mathrm{La}]$ souplesse [...] qui a toujours inspiré la surveillance des établissements financiers”. ANL, CSSF, report from the Banking Commissioner to the Minister of Finance, Pierre Werner, 4 April 1974.
} 
of funds in which several Luxembourg stakeholders were involved took place entirely away from the public gaze, despite the extremely lengthy process and the tensions raised. Indeed, in the 1980s, the Luxembourg liquidators prepared a complaint against the Luxembourg government - which was ultimately unsuccessful - and the liquidation process only came to an end in $2006^{68}$.

\section{CONCLUSION}

In 1987, the Luxembourg Chamber of Deputies discussed the adoption of a European directive on undertakings for collective investment. Often the historical narrative on investment funds only begins with this directive ${ }^{69}$. Its rapid implementation is put forward as the reason why Luxembourg is now the world's second leading centre for investment funds after the United States - but this is to ignore the historical context. In the 1987 parliamentary discussions, the 1972 regulation was held up as a sign of the "maturity" of the sector by Alex Bodry, rapporteur of the law, and not as a moment of crisis. IOS was not mentioned ${ }^{70}$.

The short memory when it comes to these events is linked in part to the way in which the IOS collapse was covered by the Luxembourg press in the 1970s. Although the national press served as a sounding board for the fall of IOS, it barely investigated Luxembourg's role, except in the early months of the "crisis" in 1970. Other arenas also remained silent: the political class, Luxembourg's investors (apart from the modest action of the Union Luxembourgeoise des Consommateurs) and the Luxembourg banking community - while in other countries, by contrast, conventional banks played a part in scandalising the behaviour of IOS, which was becoming a dangerous competitor. The main interest for the media in Luxembourg was the country's investors. The role played by Luxembourg through its virtually non-existent regulatory framework and low taxation was never addressed.

This lack of response seems to reflect a largely held consensus in Luxembourg society regarding the financial centre, then still in its early days. Rather than attributing this to the economic influence of the financial centre, which at that time was still fairly limited - in 1970 approximately 4000 people worked in credit establishments (just $3 \%$ of an active workforce of $130000^{71}$ ) - I believe that there is another more important factor at play. One aspect that comes up regularly in the literature about scandals is the modernity of mass media communication, which goes far beyond the possibilities of interpersonal communication. This raises the question as to whether scandals are possible in small countries like Luxembourg, where media communication remains interpersonal in nature given the size of the country and the interconnectedness of its various elites (political, legal, journalists, etc.). In 1954, Éric de Dampierre wrote: "In a small community where everyone knows each other and meets up every day, it would appear that there is no room for scandal" 72 . In Luxembourg, it may therefore be hard for scandals to emerge within society; they are often initially brought from outside, and it is this outside perspective that forces players within the space to react.

Consequently, we also need to move away from the national framework when analysing scandals. Already back in the $19^{\text {th }}$ century, financial scandals were often transnational, even if this interaction has rarely been addressed:

\footnotetext{
${ }^{68}$ Interview by Benjamin Zenner with Jacques Delvaux, 17 July 2019.

${ }^{69}$ M. Pauly, Histoire du Luxembourg, Brussels, PUB, 2013, p. 132.

${ }^{70}$ Chambre des Députés - Luxembourg, 1987, p. 1926.

${ }^{71}$ Statistiques historiques : 1839-1989, op. cit., p. 42.

${ }^{72}$ Originally: "Dans une petite collectivité où chacun se connaît et se rencontre chaque jour, il ne semble pas qu'il y ait place pour le scandale”. E. de Dampierre, “Thèmes pour l'étude du scandale”, Annales ESC, vol. 9, n 3, 1954, p. 332.
} 
for example, the Panama scandals are mostly analysed from the perspective of their consequences for France, but not for their impact on Panama. This case study on Luxembourg illustrates how local and global levels are closely entangled and how the question of the definition of the scandals circulates between national and transnational media arenas. This finally raises the question of whether transnational economies of values exist, how groups of people beyond national frameworks can develop as a result of international movements, and how organisations of international "moral entrepreneurs" are formed: although in the context of IOS the IASIF essentially remained a German organisation (despite its name), subsequently other organisations would be set up with more transnational vocations (for example Transparency International founded in 1993 or ATTAC set up in 1998) ${ }^{73}$.

\footnotetext{
${ }^{73}$ E. Gutterman, “The Legitimacy of Transnational NGOs: Lessons from the Experience of Transparency International in Germany and France", Review of International Studies, vol. 40, n² 2, 2014, p. 391-418.
} 